\title{
Critical Review of the Theoretical, Experimental and Computational Fluid Dynamics Methods for Designing Plate Fin Heat Exchangers
}

\author{
Natalia Salinas Libreros*, Nicolas Mancilla Mercado, Guillermo Valencia Ochoa, Jorge Duarte Forero \\ and Luis Guillermo Obregon
}

Efficient Energy Management Research Group, Mechanical Engineering Program, Univeridad del Atlantico, Barranquilla, Colombia

Received 12 August 2019; Accepted 10 December 2019

\begin{abstract}
This paper presents a detailed review of the research carried out for the design of flat fin heat exchangers is using theoretical, experimental, and computational fluid dynamics (CFD) methods. The scope and limitations of several studies are presented, as well as the critical point of view of the authors in the selection of optimal methods in the thermo-hydraulic design of each equipment. Fin heat exchangers optimization is done using different approaches. The theoretical model assumes considerations that do not fully replicate the phenomenon, the experimental method provides real parameters for the design and implies high costs, and finally, computational fluid dynamics predicts the behaviors of thermal and hydraulic machine flows, in addition to recreating the phenomena almost exactly and complement the theoretical and experimental methods. With this review, it can be verified that the methods complement each other, thus achieving greater profitability at the industrial level, greater robustness in the design, and facilitating the study of behavior from a thermo-hydraulic approach.
\end{abstract}

Keywords: CFD; Experimental methods; Heat exchanger; Numerical methods; Optimization methods; Plate-fin; Thermal efficiency.

\section{Introduction}

Thermal management of the vehicle engine is essential so that the vehicle operation is more efficient and sustainable [1]. The evolution of cooling radiators design allows us to improve and maximize the efficiency of the cooling of the engine, and consequently, the performance [2].

Currently, the heat exchangers study and design are vital in the multiple applications they have in the industry and residential sectors [3]. Therefore, it is necessary to know their operation and the main factors that influence their performance, to obtain an optimal design from the energetic point of view [4].

Due to the high compression ratio, the outlet air temperatures to the compressor of a diesel engine are so high that they generate a loss of density, which limits the oxygen contained in a given volume, reduces the combustion quality, and decreases the engine power [5]. Therefore, it is necessary to implement an air cooling systems to prevent this phenomenon, such as a louvered fin heat exchanger [6].

The evolution of the heat exchangers design goes towards the advances of technology. Optimal design for a heat exchanger before manufacturing can be achieved using a theoretical model, experimental method, and simulations employing Computational Fluid Dynamics (CFD). The theoretical model provides a limited estimate of the heat exchanger design because specific considerations are assumed that do not replicate the phenomenon completely [7]. On the other hand, the experimental method provides real

*E-mail address: nsallinas@mail.uniatlantico.edu.com ISSN: $1791-2377$ @ 2019 School of Science, IHU. All rights reserved. doi:10.25103/iestr.126.16 parameters for the construction of the exchangers, but its high cost makes it unfeasible, in addition to requiring procedures in laboratories and detailed tests [8]. Likewise, the growth in information processing capacities in the last decade has increased the use of CFD [9]. This technique is the most relevant and widely method used for the heat exchangers design, since it is capable of optimizing and predicting the behavior of the flow in different parts of the thermal and hydraulic machines before their manufacture, thus allowing its potentiation [10]. There are many commercial CFD software such as FLUENT and ANSYS, CFX, which are of high capacity to predict with certainty a product that works in the real world, achieving improvements in the final product [11].

Flat fin heat exchangers (PFHE) have been extensively researched in the last decade [12]. During that time, advances in technology, as well as the efforts of many researchers, have increased the knowledge and availability of data to evaluate the performance of this equipment on the fin side [13]. Hao J and Q. Chen [14], worked on the experimental path for the measurement of performance and correlation of the fin-side phenomenon, while J. Wen and Y. Li [15] chose the path of computational fluid dynamics for the characterization of the exchanger.

Within the investigations carried out on this subject, there are studies corresponding to the improvement of the efficiency of heat exchangers, such as N. K. Patil and M. K. Rathod [16] obtained an improvement in the efficiency of 0.8 to 0.9 of a plate-fin heat exchanger (CHE) with design variables such as surface areas and free flow areas. Also, K. Wang and Y. Wang [17] states that experimental studies require a mathematical and computational model. The CFD model is a reliable method for examining the effects of several design changes on the elements' performance and represents 


\section{Journal of Engineering Science and Technology Review 12 (6) (2019) 126 - 133}

a cost-effective route to design optimization [18]. Also, other studies present characteristics of air-side heat transfer and heat exchanger pressure drop using CFD as an experimental method, the experimental results match the predictions of Computational Fluid Dynamics (CFD) three-dimensional models [19]. Jin-Seong and B. Sungjoon [20] worked on the efficiency and thermal efficiency of a heat exchanger with vortex-generating fins, in the center of the fin. They used a 3D computational analysis to know the characteristics of the airflow and fin temperature in the heat exchanger under dry conditions. They observed the behavior of frost and the variation in the thermal efficiency of the exchanger, improved thermal performance in dry conditions by $12 \%$.

$\mathrm{T}$ he main contribution of this research article is to present a detailed review of the design of flat fin heat exchangers using theoretical, experimental, and computational fluid dynamics methods. The scope and limitations of each study are presented, as well as the authors' point of view, for the selection of the appropriate study method when a thermohydraulic optimization of this type of equipment is desired. Additionally, bibliometric indicators are presented, such as the number of publications per year, geographical location from the research results in this type of exchangers, which have the potential to familiarize and guide researchers to discover new trends, topics, and existing gaps that require additional research.

\section{Initiations of research on flat fin heat exchangers}

In its early days, heat transfer has been of critical importance in almost all areas of engineering and technology [21]. For several decades, engineers and scientists worked on the solution of these problems, in $1960 \mathrm{H}$. Auracher [22] conducted studies on the subject, achieving the rapid growth of the industry, the field of heat transfer had improved to the point of generating great interest in the application of heat exchangers. In 1994 E. N. Lightfoot [23] conducted research introducing improved heat transfer, its characteristics, and utility, increased friction losses over balancing gains in heat transfer rates, achieving a very useful discussion of savings in capital cost and surprisingly modest exchanger size.

In 1996 experimental studies [24] on plate-fin heat exchangers with different geometric parameters, stated results that the separation of the fins does not affect the heat transfer coefficient, and the number of rows of tubes has a negligible effect on the friction factor, and the thickness of the fins does not affect the heat transfer or friction characteristics. Failure analysis and life prediction of a large and complex fin plate heat exchanger required metallurgical analysis, developing a model for thermal and stress analysis, and a fatigue model [25].

In 1997 B. Kundu [26] determines a study for optimal fin dimensions for fin-tube heat exchangers. The optimization is carried out by a classical bypass method. Based on mathematical analysis, design curves have been made to design optimal fins. In 1999 he implemented a dynamic simulator of the ProSectm Sealed Plate Fin Heat Exchangers (PFHEs) for a rigorous model that allows representing the wide range of configurations for this type of equipment [27]. Also, it is evident the implementation of a design methodology of compact plate-fin heat exchangers in the total use of pressure drop as the main design objective[28]. A thermohydraulic model is developed, representing the relationship between pressure drop, heat transfer coefficient, and exchanger volume [29].
In 2005, the influence of longitudinal heat conduction through plate heat exchangers and counter-flow fins with the double cold channel was analyzed. Plate fin heat exchangers are increasingly used due to their high efficiency and compactness [30].

\section{Research studies on flat fin heat exchangers.}

In recent years, the processing capacity and speed of computers have progressively increased [31], and interest in the use of numerical methods, such as Finite Element Methods and Finite Differences, to solve problems governed by differential equations has increased significantly [32]. Many complicated engineering problems can now be solved with computers at a low cost and in a very short time [33].

\subsection{Theoretical methods}

In the study of a theoretical model, heat flow (Q), heat transfer area (A), global heat transfer coefficient (U) and mean temperature difference $(\mathrm{dTm})$ are presented; these variables lead to the dimensioning of a heat exchanger, obtaining the heat transfer area [34]. Besides, a set of equations is established for the model: the heat transfer equation and the heat balance equation of the heat exchangers [35] [36].

Optimizing heat transfer is the practice of modifying a heat transfer surface or cross-section of the flow [37]. Proper modification of geometric parameters improves heat transfer in the heat exchanger, provides an experimental database on heat transfer [38] [39].

It should be noted that the models developed in parameters are based on mathematical description models, so Sun H[40] was based on the theory of graphs developing a model of thermal performance of parameters distributed in the heat exchanger, which reflect the temperature gradients along with the axial and transverse directions. Subsequently, Marković S et al. [41] demonstrated that parameters such as vacuum velocity and others could be successfully used to correlate heat transfer and pressure drop parameters.

Chen T y Wang J [42] studied the effects of different plate-fin heat exchanger structures numerically, analyzed four fin structures Figure 1 and four working conditions to examine the performance of the plate-fin heat exchanger with detailed analyses of velocity, pressure, temperature, and heat transfer distributions.
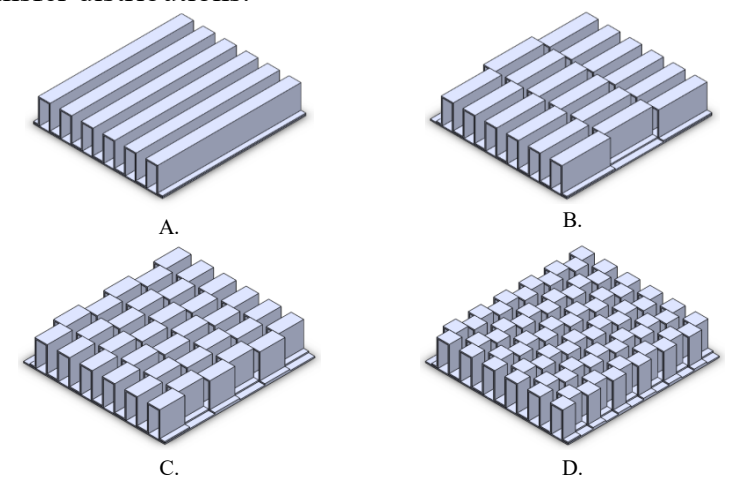

Fig 1. Four models of plate-fin heat exchangers

Zhou G. et al. [43] studied air to air fin plate (PFHE), heat exchangers. From empirical correlations dedicated to air-toair PFHE, they constructed mathematical models of heat transfer and resistance to flow that considered the impacts of changes in air flows and temperatures. 
Wen J. and Li K. [44] conducted a numerical study on the integral performance of wavy sinusoidal fins in PFHE based on the analysis of fluid-structure interaction (FSI), the results revealing that the factor $j$ increases with increasing fin spacing and height, and decreases with increasing fin thickness, wavelength, and input velocity.

However, one efficient modeling method is the plate heat exchanger (PHE), which employs sensitivity analysis to study the influence of parameters on model output. The Gaussian mix (GMM) model is used to track the output cooling temperature caused by these factors [45].

Indeed, Kays and London [46] propose various configurations on the study of the fins for the surface selected for the plate, new data, and more modern theoretical solutions for the flow in the simple geometries. Thus, N. K. Patil and Table 1. Summary of theoretical method.
M. K. Rathod conducted a numerical investigation of the effect of the operating parameters on the plate-fin heat exchanger (CHE) [16]. Other studies find designs of heat exchangers using the logarithmic mean temperature (LMTD) method, where the hydraulic and thermal performance of the heat exchanger were experimentally investigated [19].

The correlation between heat transfer and fin flow friction characteristics is the basis for the optimization of heat exchangers[47] [48]. It is of great importance to developing accurate formulas, in which the case of experimental research and numerical simulation methods are two effective means.

This behavior is similar to the hydrokinetic turbine simulations performed by S. Laín [12] and Y. M. Dai [13], where the CFD curve was above the DMST.

\begin{tabular}{|c|c|c|c|}
\hline Heat Exchanger & Method & Parameters & Result \\
\hline Shell and tube & $\begin{array}{l}\text { A genetic algorithm, } \\
\text { The constructal theory. }\end{array}$ & $\begin{array}{l}\text { Thermal efficiency, } \\
\text { Cost. }\end{array}$ & $\begin{array}{l}\text { Increase in the thermal efficiency is more } \\
\text { than } 28 \%\end{array}$ \\
\hline Plate and fin & Genetic algorithm. & $\begin{array}{l}\text { Geometric parameters, } \\
\text { Total rate of heat } \\
\text { transfer, } \\
\text { The total annual cost. }\end{array}$ & $\begin{array}{l}\text { The effect of some geometric parameters } \\
\text { on each heat transfer and total cost. }\end{array}$ \\
\hline Plate fin & Steady State model & Operating parameters & $\begin{array}{l}\text { A tool disegn that calculated surface } \\
\text { areas, free flow areas and exchanger core } \\
\text { size for the given operating parameters of } \\
\text { cross flow with effectiveness from } 0.8 \text { to } \\
0.9 \text {. }\end{array}$ \\
\hline Plate (PHE) & $\begin{array}{l}\text { Mechanistic model } \\
\text { according to heat transfer } \\
\text { equation and heat balance } \\
\text { equation, } \\
\text { Gaussian mixture model } \\
\text { (GMM). }\end{array}$ & $\begin{array}{l}\text { Geometric parameters, } \\
\text { Operating parameters. }\end{array}$ & $\begin{array}{l}\text { Developed a model to optimized energy- } \\
\text { saving of circulating cooling water system } \\
\text { in a steel plant. }\end{array}$ \\
\hline Plate Fin & $\begin{array}{l}\text { Empirical correlations, } \\
\text { Mathematical models of } \\
\text { the heat transfer and the } \\
\text { flow resistance. }\end{array}$ & $\begin{array}{l}\text { Air flow rates and } \\
\text { temperatures. } \\
\text { Nominal parameters. }\end{array}$ & $\begin{array}{l}\text { A model that can predict the results with } \\
\text { a relative deviation less than } 10 \% \\
\text { compared to the experimental data. }\end{array}$ \\
\hline parallel plate-fin & $\begin{array}{l}\text { Distributed-parameter } \\
\text { model based on graph } \\
\text { theory. }\end{array}$ & $\begin{array}{l}\text { Number of HE, } \\
\text { Geometric parameters, } \\
\text { Mass flow rate } \\
\text { distribution. }\end{array}$ & $\begin{array}{l}\text { The deviations of the heat capacity and } \\
\text { outlet temperature of natural gas from } \\
\text { experimental data were }-1.9 \% \text { and } \\
+4.35^{\circ} \mathrm{C} \text {, respectively. }\end{array}$ \\
\hline
\end{tabular}

\subsection{Experimental models}

The experimental studies are based on theoretical studies, which, after being mathematically based, were validated using heat exchangers[49]. Results were obtained with high accuracy concerning the theory employing verifications, discovering optimal parameters which were built as proof [50].

Each experimental study is carried out to verify a hypothesis or a scientific principle [51]. Studies in heat exchangers are based on mathematical and computational models [52]. Numerically studied factors such as heat transfer coefficients, flow resistance, thermal performance, accuracy, and precision of the simulation method, and results are confirmed by experiments [17].

M. Mobtil and D. Bougeard [53] experimentally determined the distribution of the transient heat transfer coefficient over the second-row fin of a tube heat exchanger assembly with stepped fins. On the other hand, H. Liu et al. [54] manipulated the tube geometry to model the flow field through the heat exchanger.

T. Xiaoping [55] investigated the heat transfer and air pressure drop characteristics of the Microchannel Heat
Exchanger (MCHX) with flat tube grate fin Figure 2. The test samples were not sufficient to thoroughly investigate track performance, so the main objective of the experimental research was to provide effective data to validate the CFD model.
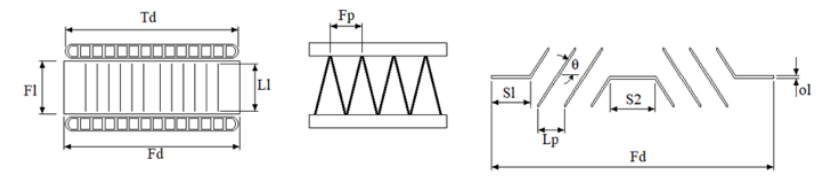

Fig 2. Geometric parameters of MCHX and shutter fins

On the other hand, H. Yang et al. [36] conducted experimental research using the R113 liquid to study the thermohydraulic characteristics of the plate-fin heat exchanger with smooth, toothed, and perforated fins. They used three performance evaluation criteria $\mathrm{j} / \mathrm{f}, \mathrm{j} / \mathrm{fl} / 2$, and $\mathrm{j} / \mathrm{fl} / 3$ to compare their overall performance qualitatively. Also, to study the effects of the heating condition and Prandtl's number on heat transfer, they created a numerical model of toothed fins, guiding the design of the plate-fin heat exchanger. 


\section{Journal of Engineering Science and Technology Review 12 (6) (2019) 126 - 133}

On the one hand, M. Khoshvaght et al. [56] compared seven common channel configurations used in plate-fin heat exchangers (smooth, perforated, strip compensated, corrugated, corrugated, corrugated, vortex-generator, and bolt). To evaluate the performance of these channels and also select an optimal plate-fin channel, they used three energybased performance evaluation criteria. On the other hand, D. Taler and J. Taler [62] used different procedures to calculate the friction factor of low load plate and tube heat exchangers to present a new two-pass car radiator design with two rows of tubes, proposing a procedure to determine heat transfer correlations in heat exchangers with different constructions.
The experimental results of the exhibited articles provide a new scheme for the structural improvement of heat exchangers, providing references for further optimization of their performance. Also from defining and explaining the factors that affect the design margins of a heat exchanger and its improvement [57], it can be concluded that although the experimental study is very useful, it is not the most appropriate method to give optimal results, it is necessary a complementary methodology that gathers unknown geometric parameters [58].

Table 2. Summary of experimental method

\begin{tabular}{|c|c|c|c|}
\hline Heat Exchanger & Method & Parameters & Result \\
\hline plate-fin & $\begin{array}{l}\text { Variation of flow } \\
\text { distribution and type of } \\
\text { fluid. }\end{array}$ & $\begin{array}{l}\text { Operating } \\
\text { parameters, } \\
\text { Thermal }\end{array}$ & $\begin{array}{l}\text { The values of Sliq, Sgas and Sdry decrease by } 5.4 \\
44.0 \%, 4.7-35.0 \% \text { and } 11.7-30.0 \% \text {, respectively. }\end{array}$ \\
\hline $\begin{array}{l}\text { staggered finned } \\
\text { tube }\end{array}$ & Inverse method & $\begin{array}{l}\text { Heat transfer } \\
\text { coefficient } \\
\text { distribution over } \\
\text { the fin of the } \\
\text { second row }\end{array}$ & $\begin{array}{l}\text { The high accuracy of the inverse process in } \\
\text { determining heat transfer coefficient spatial } \\
\text { distribution }\end{array}$ \\
\hline $\begin{array}{l}\text { plate-fin with } \\
\text { plain, serrated and } \\
\text { perforated fins. }\end{array}$ & $\mathrm{j} / \mathrm{f}, \mathrm{j} / \mathrm{fl} / 2$ and $\mathrm{j} / \mathrm{fl} / 3$ & $\begin{array}{l}\text { Geometric } \\
\text { parameters, } \\
\text { flow conditions. }\end{array}$ & the performance of serrated fins is the best. \\
\hline
\end{tabular}

\subsection{CFD modeling and analysis of the phenomenon}

Computational fluid dynamics uses numerical methods to solve problems in the area of fluid mechanics, thermals, emissions, aerodynamics [59]-[62]. The main objective of the CFD in experimental research is to provide useful data to validate the model [63]. Likewise, the CFD is used as an experimental method for detailed investigations of the flow field and the heat transfer efficiency of the heat exchanger applied to Diesel engines [19].

As seen in research such as that of S. Alfarawi [64] he design and optimization of exchangers require a theoretical basis, followed by experimental research and CFD modeling, a consequence of previous studies. Theoretical and practical studies [65][66] in the field of heat transfer in finned heat exchangers use the CFD method as a complement to other methods, the numerical prediction of fluid flow distribution shows a good concordance with the experimental measurement [67]. Thus, H.T. Chen et al. [55] characterized the heat transfer and air pressure drop of the microchannel heat exchanger (MCHX) with flat tube grate fin using both the CFD and the experimental methods. The test samples were not sufficient to thoroughly investigate the track performance, so the main objective of the experimental research was to provide effective data to validate the CFD model. This model was established to predict the flow characteristics in the area of influence and heat transfer. Experimental data in the area of operations were reduced using the effectiveness-NTU method. A comparison between CFD simulations and experimental data showed that the established CFD model had the very good predictive capability. Based on the results of the CFD simulation, some optional configuration parameters were proposed for the flat tube grid fins.

On the other hand, K. Boukhadia and H. Ameur [68] perform numerical simulations for a fin heat exchanger for a Vortex Tube, the rectangular and perforated wings are used to improve performance and heat transfer rates. New correlations were established for the prediction of friction factor and Nusselt number as a function of Reynolds number and deflector perforation shape. Likewise, A.M. González et al. [69] presented a numerical-experimental hybrid approach to obtain the thermal performance of heat exchangers. The proposed methodology combines numerical simulation with the data applied to a tube heat exchanger with plate fins with the in-line arrangement; the validation was comparing the results with empirical correlations for the number of Nusselt available in the literature.

In particular, R. Song [70] studied the correlation of heat transfer and flow friction characteristics of fins for hydrodynamics, stressing the importance of developing generally accurate formulas for optimization, adopting Fluent for numerical simulation. They obtained good agreements between numerical simulation and the Manglik \& Bergles correlation [37], which validates the reliability of the numerical simulation method

Over time, H.T. Chen [71] performed a hybrid method of commercial CFD software and inverse method with experimental data and various flow models to study heat transfer by natural convection. The finite difference method was used together with the experimental temperature data. It was first applied to estimate the heat transfer coefficient in the fins and CFDs along with several flow models. Then, it estimated heat transfer coefficients to determine the air temperature and air velocity profiles, the surface temperature of the fin, and the heat transfer coefficient.

Consequently, it was obtained more precise numerical results, an appropriate flow model with the number of grid points, the number of iterations, and the relative convergence criteria when the resulting heat transfer coefficient and fin temperature are as close as possible to the inverse results and the experimental temperature measurements. Also, N. Piroozfam and A. Shafaghi [35] investigated the thermal performance and fluid characteristics of computational Counterflow Heat Exchangers (CFHEs), making modifications to the plate geometry with which they achieved 


\section{Journal of Engineering Science and Technology Review 12 (6) (2019) 126 - 133}

the increased heat transfer rate (HTR). Also, the theoretical optimization of plate-fin heat exchangers was combined with CFD simulation [72]. C. Liu et al. [73] performed CFD simulation and multi-objective optimization to improve the performance of the original PFHE exchanger. With geometry modifications and parameter variation overcome the weaknesses of the traditional method by numerical simulation, and greatly improved the efficiency, the hot flow temperature was reduced by $18.95 \%$ and cold flow increased by $16.13 \%$; hot flow pressure drops and cold flow increased by $80 \%$ and $60 \%$; the optimized velocity had also been significantly improved.
Briefly, the experimental results fit well with the predictions of even better three-dimensional CFD models [74], From this, it is presumed to teach that the CFD model is a reliable method for examining the effects of a number of design changes on the elements' performance, representing a cost-effective route for design optimization [73]. CFDs have become an effective tool in several heat exchangers; it is almost sure to be less expensive than experimental characterization studies [18].

Table 3. Summary of computational fluid dynamics methods

\begin{tabular}{|c|c|c|c|}
\hline Heat Exchanger & Method & Parameters & Result \\
\hline Sinusoidal fin plate & $\begin{array}{l}\text { The Multiobjective } \\
\text { Genetic Algorithm } \\
\text { (MOGA), } \\
\text { The interaction of the } \\
\text { fluid structure (FSI). }\end{array}$ & $\begin{array}{ll}\text { Factor JF } & (\mathrm{JF}=\mathrm{j} / \mathrm{f} 1 / 3), \\
(\mathrm{JF}=\mathrm{j} / \mathrm{fl} / 2), & (\mathrm{JF}=\mathrm{j} / \mathrm{fl} / 2), \\
(\mathrm{JF}=\mathrm{j} / \mathrm{fl}) . & \end{array}$ & $\begin{array}{l}\text { The optimization results show that } \\
\text { optimum design factor JF } 1,2 \text { and } 3 \\
\text { increases by } 11.0 \%, 8.4 \% \text { and } 15.9 \% \\
\text { respectively, and the maximum stress } \\
\text { decreases by } 32.3 \%, 42.4 \% \text { and } 20.7 \% \\
\text { respectively. }\end{array}$ \\
\hline $\begin{array}{l}\text { Microchannel(MCHX) } \\
\text { with flat tube grate fin }\end{array}$ & $\begin{array}{l}\text { CFD simulation, } \\
\text { Effectiveness-NTU } \\
\text { methods. }\end{array}$ & $\begin{array}{l}\text { louver fin, involving fin } \\
\text { pith, louver angle, louver } \\
\text { pitch, louver length and } \\
\text { flow depth. }\end{array}$ & $\begin{array}{l}\text { The variation tendencies of air-side } \\
\text { performance with those parameters } \\
\text { studied were obtained and based on CFD } \\
\text { simulation results, some optional } \\
\text { configuration parameters for flat-tube } \\
\text { louver fin were proposed. }\end{array}$ \\
\hline $\begin{array}{l}\text { Welded plate (WPHE) } \\
\text { with straight gas } \\
\text { channels and } \\
\text { corrugated water } \\
\text { channels }\end{array}$ & $\begin{array}{l}\text { CFD simulation, } \\
\text { Grey's Relational } \\
\text { Analysis model. }\end{array}$ & $\begin{array}{l}\text { Long axis, short axis and } \\
\text { plate spacing }\end{array}$ & $\begin{array}{l}\text { The optimal combination of these factors } \\
\text { gave the WPHE the greatest heat transfer } \\
\text { coefficient of } 70 \mathrm{~W} / \mathrm{m} 2{ }^{\circ} \mathrm{C} \text { and a low } \\
\text { pressure drop of } 30 \mathrm{~Pa} \text {. }\end{array}$ \\
\hline $\begin{array}{l}\text { Air-Air Heat } \\
\text { Exchanger }\end{array}$ & Numerical method & Chang the tube geometry & $\begin{array}{l}\text { The results showed that the pressure } \\
\text { drop of the improved heat exchanger } \\
\text { reduced by over } 10 \% \text { and heat transfer } \\
\text { increased by almost } 25 \%\end{array}$ \\
\hline $\begin{array}{l}\text { Mini-channel } \\
\text { regenerative heat } \\
\text { exchangers }\end{array}$ & Single-blow method & Long axis and short axis & $\begin{array}{l}\text { It had the highest interstitial heat transfer } \\
\text { coefficient due to the increased specific } \\
\text { surface area }\end{array}$ \\
\hline $\begin{array}{l}\text { Plate fin-and-tube heat } \\
\text { exchangers }\end{array}$ & $\begin{array}{l}\text { The modified method } \\
\text { of determining the } \\
\text { average heat transfer }\end{array}$ & $\begin{array}{l}\text { the mean value of thermal } \\
\text { contact resistance between } \\
\text { the fin and tube was } \\
\text { estimated }\end{array}$ & $\begin{array}{l}\text { The method proposed allows predicting } \\
\text { heat transfer correlations }\end{array}$ \\
\hline $\begin{array}{l}\text { Plate fin and tube heat } \\
\text { exchangers }\end{array}$ & Numerical method & $\begin{array}{l}\text { fin tube center location, fin } \\
\text { height, tube thickness, tube } \\
\text { ellipticity, and distance } \\
\text { between fins on heat } \\
\text { transfer between flue gas } \\
\text { and water }\end{array}$ & $\begin{array}{l}\text { Greater heat transfer and pressure drop } \\
\text { values are obtained as the fin height is } \\
\text { increased, due to the increased heat } \\
\text { transfer surface area. }\end{array}$ \\
\hline $\begin{array}{l}\text { Plate-finned heat } \\
\text { exchangers }\end{array}$ & Hybrid methodology & $\begin{array}{l}\text { The airflow velocity } \\
\text { (Reynolds number) and fin } \\
\text { materials (aluminium, } \\
\text { carbon steel and copper) } \\
\text { upon the heat transfer } \\
\text { characteristics }\end{array}$ & $\begin{array}{l}\text { The main results indicate an increase of } \\
\text { the average convective heat transfer } \\
\text { coefficient with air velocity; whereas the } \\
\text { overall fin surface efficiency presents an } \\
\text { opposite behaviour }\end{array}$ \\
\hline
\end{tabular}

\section{Prospective Investigations on Flat Fin Heat Exchangers}

Theoretical and experimental researches in the area of heat transfer have always sought to complement each other solidly and consistently to validate each of the considerations and scope of the theoretical models. Over the years, research has improved with technological advances in the computational area, although this implementation known as CFD, had its beginnings around 1996[18], based on mathematical and logarithmic models, which evolved with improvements in computer equipment and algorithms. Figure 3 shows the evolution of the research methods, shows the advances of the CFD implementation to the researches. The historical evolution of the volume of publications shows the importance of the implementation of the CFD for the analysis of the phenomenon in flat fin heat exchangers, which highlights an increase of $310 \%$ from 2008 to 2018 thanks to the advance in computational means which allows reducing the calculation time. If the production trend continues, in the 
following decade (2028), it is possible to double the production volume of the last decade. Likewise, it is expected that for that same year, the volume of publications with the experimental method will increase by $76 \%$ concerning 2018 , in response to the need to validate such computational studies. However, given the advantage of the theoretical method of reducing costs and design in experiments, it will also increase, reaching a volume of around 1416 publications at the end of the same year maintaining the trend of the last decade.

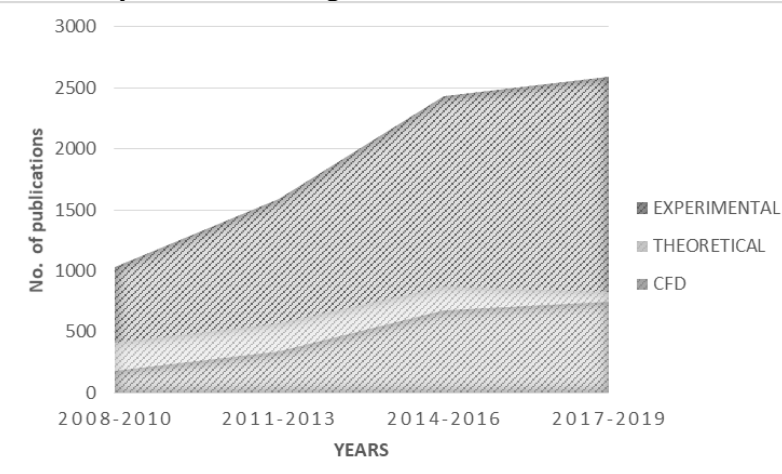

Fig 3. Number of annual publications. Source Authors

The field of action of CFD studies is becoming wider and wider, which is classified according to the tool used to model or solve the turbulence equations. Thus the CFD increases the prediction of several characteristics of flow and heat transport, becoming an attractive and complementary practice [75].

It happened an increase in the number of studies of heat exchangers conducted in the last 10 years, as shown in Figure 4. In addition, there has been an improvement in the quality of research results which is reflected in the local and global citation indicators, given that the 2009 publications have achieved a Global Citation Index (GCCI) of $16.6 \%$ in the 2008-2018 ranges and a Local Citation Index (LCCI) of $16.1 \%$, indicators that by 2013 have GCCI values of $13.3 \%$ and a GCCI of $12.9 \%$.

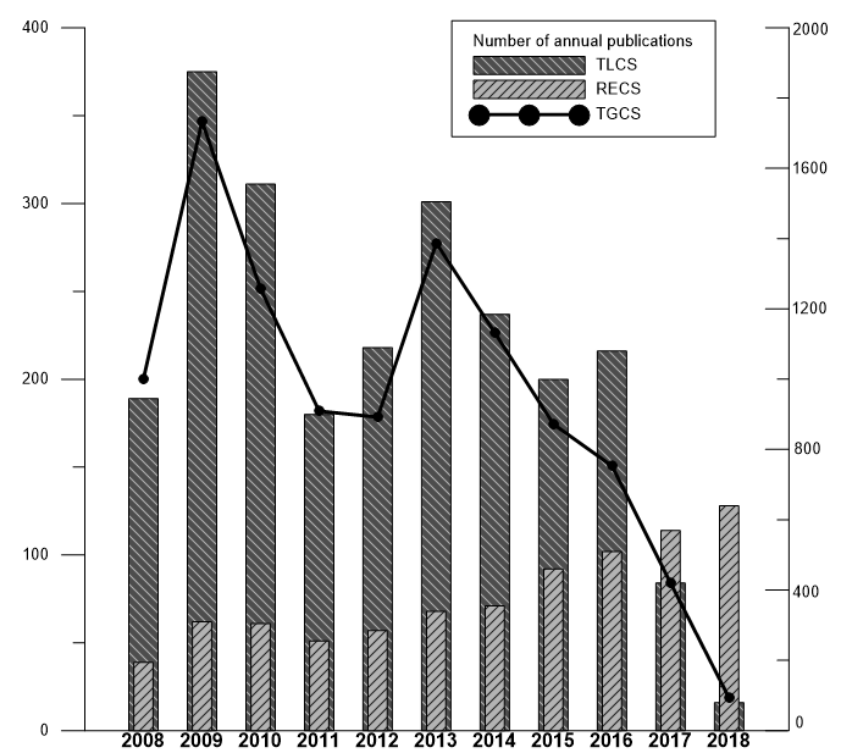

Fig 4. Table of annual publications (2008-2018). Source Authors

Figure 5 shows the worldwide participation of countries in the publication of articles, being the People's Republic of China the one that has participated more in publications in these last 10 years with 258 publications, which represents $30.3 \%$ of world publications, followed by the United States with 87 publications for $10.2 \%$ participation and India with 83 publications with $9.7 \%$ participation.

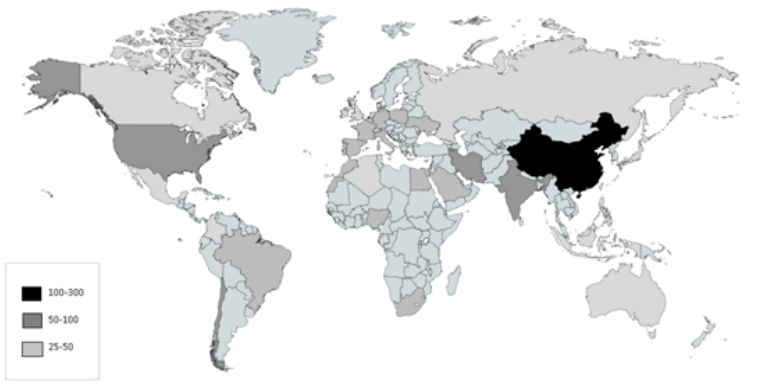

Fig 5. Map of participation in publications

From the analysis of the keywords considered in a sample of 852 published articles, it is possible to study the trend of interest and focus of research in plate heat exchangers in the three selected time intervals, as shown in Figure 6. It is possible to evidence the significant advance in research and development of computational technologies at the service of plate heat exchangers CFD, given the increase of the words 'CFD,' 'Numerical' and 'Experimental' from 33.3\%, 50\% and $81.8 \%$ from the second to the third period. The promising growth that the words 'optimization' and 'CFD' may have is highlighted, like the third study period under consideration begins to have a presence in the critical words declared by the authors of the documents under consideration.

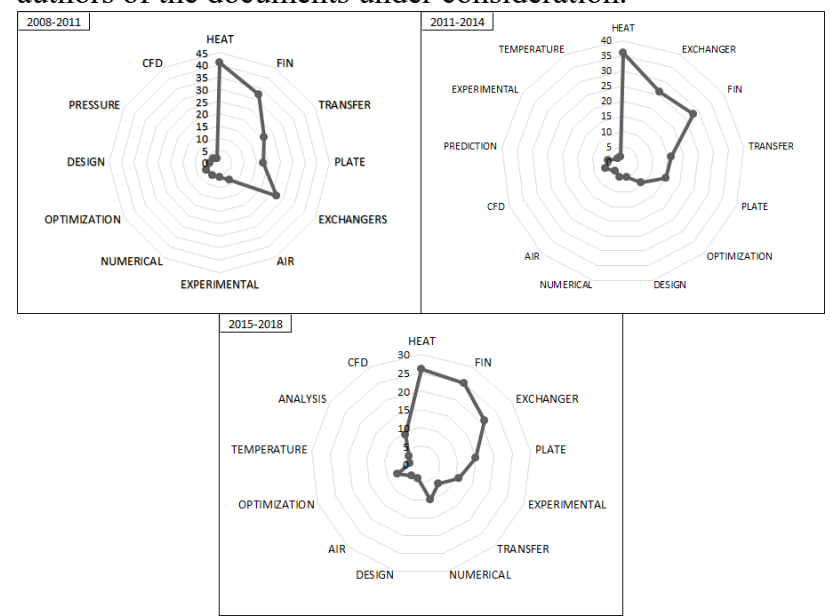

Fig 6. Radial map with keyword trend change between 2008 and 2018.

\section{Conclusions}

The present article is a compilation of information on the most exceptional researches in the subject and its advance in the methods of investigation to have foundations for future investigations.

Based on the research, it is highlighted that the interest in the subject began in 1995; however, until 2011, there was the expansion of the subject with the complement of the three research methods. However, the importance of the theoretical basis was fundamental in the implementation of the CFD, and the experimental as a method of real verification. The main conclusions drawn from the review are as follows:

- Many heat transfer studies around the world focus on the modification of geometric parameters. Many of the investigations showed an increased efficiency and performance of heat exchangers with the change of geometry, thus achieving an improved heat transfer as well as lower costs in optimizing fin heat exchangers. 


\section{Journal of Engineering Science and Technology Review 12 (6) (2019) 126 - 133}

- With the addition of the experimental method to the theoretical studies, it was obtained the verification of the principle raised by each mathematical model with the test of the optimal parameters. However, as technology advances, the test samples were not sufficient to thoroughly investigate the performance on the track.

- Fortunately, many of these studies and reports revealed the far-reaching scope of CFD modeling as a reliable method for examining the effects of several design changes of elements on their performance, in addition to the revenue for optimization of this. Also, this technique is used in the industry for the possibility of knowing the behavior with details of a system.

In summary, there are three methods of investigation that work in the complement of the other one, when using this combination of investigation methods one can obtain results with a high degree of reliability for the diverse applications of the industry and the home, considering that the devices of heat transference are everywhere.

If the trends continue, the CFD modeling will take more participation in the following years concerning the other methods of study, being that this has a slope of higher growth. It can also be noted in the increase of publications that mention it as a crucial part of these studies.

This is an Open Access article distributed under the terms of the Creative Commons Attribution License

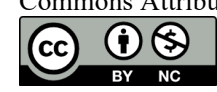

\section{References}

[1] C. A. Romero Piedrahita, "Contribución al conocimiento del comportamiento térmico y la gestión térmica de los motores de combustión interna alternativos.” 2009.

[2] S. Subudhi and A. Kumar, "Application of Nanofluids for Radiator Cooling," Ref. Modul. Mater. Sci. Mater. Eng., pp. 1-9, 2019.

[3] O. Arsenyeva, J. Tran, M. Piper, and E. Kenig, "An approach for pillow plate heat exchangers design for single-phase applications," Appl. Therm. Eng., vol. 147, pp. 579-591, Jan. 2019.

[4] J.-Y. Jang and C.-C. Chen, "Optimization of louvered-fin heat exchanger with variable louver angles," Appl. Therm. Eng., vol. 91, pp. 138-150, Dec. 2015.

[5] N. Ramesh and J. M. Mallikarjuna, "Low temperature combustion strategy in an off-highway diesel engine - Experimental and CFD study," Appl. Therm. Eng., vol. 124, pp. 844-854, Sep. 2017.

[6] J. Ammann, P. Ruch, B. Michel, and A. R. Studart, "Quantification of heat and mass transport limitations in adsorption heat exchangers: Application to the silica gel/water working pair," Int. J. Heat Mass Transf., vol. 123, pp. 331-341, Aug. 2018.

[7] E. Aursand and T. Ytrehus, "Comparison of kinetic theory evaporation models for liquid thin-films," Int. J. Multiph. Flow, vol. 116, pp. 67-79, Jul. 2019.

[8] Ł. Amanowicz, "Influence of geometrical parameters on the flow characteristics of multi-pipe earth-to-air heat exchangers experimental and CFD investigations," Appl. Energy, vol. 226, pp. 849-861, Sep. 2018.

[9] J. Ge, W. Tian, S. Qiu, and G. H. Su, "CFD simulation of secondary side fluid flow and heat transfer of the passive residual heat removal heat exchanger," Nucl. Eng. Des., vol. 337, pp. 27-37, Oct. 2018.

[10]M. S. Lee, Z. Li, J. Ling, and V. Aute, “A CFD assisted segmented control volume based heat exchanger model for simulation of air-torefrigerant heat exchanger with air flow mal-distribution," Appl. Therm. Eng., vol. 131, pp. 230-243, Feb. 2018.

[11]I. (C) ANSYS, "ANSYS," (C) ANSYS, Inc. p. http://www.ansys.com/es_es, 2014.

[12] S. Wang, Y. Li, J. Wen, and Y. Ma, "Experimental investigation of header configuration on two-phase flow distribution in plate-fin heat exchanger," Int. Commun. Heat Mass Transf., vol. 37, no. 2, pp. 116-120, Feb. 2010.

[13] M. H. Sharqawy and S. M. Zubair, "Efficiency and optimization of straight fins with combined heat and mass transfer - An analytical solution," Appl. Therm. Eng., vol. 28, no. 17-18, pp. 2279-2288, Dec. 2008.

[14]J.-H. Hao, Q. Chen, J.-X. Ren, M.-Q. Zhang, and J. Ai, “An experimental study on the offset-strip fin geometry optimization of a plate-fin heat exchanger based on the heat current model," Appl. Therm. Eng., vol. 154, pp. 111-119, May 2019.

[15]J. Wen, Y. Li, A. Zhou, and K. Zhang, "An experimental and numerical investigation of flow patterns in the entrance of plate-fin heat exchanger," Int. J. Heat Mass Transf., vol. 49, no. 9-10, pp. 1667-1678, May 2006.

[16]N. Patil and M. Rathod, "Numerical Investigation on Effect of Operating Parameters on Plate Fin Heat Exchanger," Proc. World Congr. Eng., vol. III, pp. 4-9, 2012.

[17]X. Gu, Y. Luo, X. Xiong, K. Wang, and Y. Wang, "Numerical and experimental investigation of the heat exchanger with trapezoidal baffle," Int. J. Heat Mass Transf., vol. 127, pp. 598-606, Dec. 2018.
[18]W. D. Griffiths and F. Boysan, "Computational fluid dynamics (CFD) and empirical modelling of the performance of a number of cyclone samplers," J. Aerosol Sci., vol. 27, no. 2, pp. 281-304, Mar. 1996.

[19] L. Haiying, L. Duo, Y. Xiao, L. Yi, S. Yi, and D. Wei, "Study of the Pressure Drop and Thermal Performance of an Air-Air Heat Exchanger for Aero-engine Application," Procedia Eng., vol. 99, pp. 812-821, 2015.

[20] J.-S. Park, S. Byun, D. R. Kim, and K.-S. Lee, "Frost behavior of a louvered fin heat exchanger with vortex-generating fins," Int. J. Heat Mass Transf., vol. 114, pp. 590-596, Nov. 2017.

[21] Y. Jiang, E. Li, X. Q. Zhang, Q. G. Wu, and Y. H. Yap, "Superposition method for the simulation of heat transfer," Int. J. Heat Mass Transf., vol. 120, pp. 914-922, May 2018.

[22] H. Auracher, "Principles of Enhanced Heat Transfer: Ralph L. Webb John Wiley \&amp; Sons, Inc. (1994) 576 pp, 70, \$98, ISBN 0 47157778 2," Int. J. Refrig., vol. 18, no. 8, p. 565, Jan. 1995.

[23]E. N. Lightfoot, "Principles of enhanced heat transfer: By R. L. Webb, Wiley, New York, 1994, ISBIN \#0-471-57778-2 556 pp," Chem. Eng. Sci., vol. 50, no. 18, p. 3007, Sep. 1995.

[24] C.-C. Wang, Y.-J. Chang, Y.-C. Hsieh, and Y.-T. Lin, "Sensible heat and friction characteristics of plate fin-and-tube heat exchangers having plane fins," Int. J. Refrig., vol. 19, no. 4, pp. 223-230, May 1996.

[25]P. Carter, T. J. Carter, and A. Viljoen, "Failure analysis and life prediction of a large, complex plate fin heat exchanger," Eng. Fail. Anal., vol. 3, no. 1, pp. 29-43, Mar. 1996.

[26] B. Kundu and P. . Das, "Optimum dimensions of plate fins for fintube heat exchangers," Int. J. Heat Fluid Flow, vol. 18, no. 5, pp. 530-537, Oct. 1997.

[27]D. Averous, K. Hammadi, H. Pingaud, X. Joulia, and P. Guittard, "Dynamic simulation of Brazed Plate-Fin Heat Exchangers," Comput. Chem. Eng., vol. 23, pp. S447-S450, Jun. 1999.

[28] M. Picon-Nuñez, G. T. Polley, E. Torres-Reyes, and A. GallegosMuñoz, "Surface selection and design of plate-fin heat exchangers," Appl. Therm. Eng., vol. 19, no. 9, pp. 917-931, Sep. 1999.

[29] J.-M. Reneaume, H. Pingaud, and N. Niclout, "Optimization of Plate Fin Heat Exchangers: A Continuous Formulation," Chem. Eng. Res. Des., vol. 78, no. 6, pp. 849-859, Sep. 2000.

[30] T. C. Mi, Y. Z. Li, J. Wang, and Y. H. Zhu, "Performance analysis of counter flow plate-fin heat exchangers considering the effect of longitudinal conduction," Proc. Twent. Int. Cryog. Eng. Conf., pp. 777-780, Jan. 2005.

[31] O. C. Zienkiewicz, El método de los elementos finitos. Reverté, 1981.

[32]E. Steiner, Matemáticas para las ciencias aplicadas. Reverté, 2005.

[33] M. N. Ozisik, "Finite-Difference Methods," Heat Conduct., 1993.

[34]F. P. Incropera and D. P. DeWitt, Fundamentos de transferencia de calor. 1999.

[35]N. Piroozfam, A. Hosseinpour Shafaghi, and S. E. Razavi, "Numerical investigation of three methods for improving heat transfer in counter-flow heat exchangers," Int. J. Therm. Sci., vol. 133, pp. 230-239, Nov. 2018.

[36] H. Yang, J. Wen, S. Wang, and Y. Li, "Effect of fin types and Prandtl number on performance of plate-fin heat exchanger: Experimental and numerical assessment," Appl. Therm. Eng., vol. 144, pp. 726735, Nov. 2018. 
[37]F. Kreith, M. S. Bohn, and R. M. Manglik, Principios de transferencia de calor. Cengage Learning Editores, 2012.

[38] S. Song, H. Shan, J. Liu, and B. Li, "Heat transfer study of PVDF hollow fiber heat exchanger for desalination process," Desalination, vol. 446, pp. 1-11, Nov. 2018.

[39]T. Muszynski, "The influence of microjet array area ratio on heat transfer in the compact heat exchanger," Exp. Therm. Fluid Sci., vol. 99, pp. 336-343, Dec. 2018.

[40]H. Sun et al., "A general distributed-parameter model for thermal performance of cold box with parallel plate-fin heat exchangers based on graph theory," Appl. Therm. Eng., vol. 148, pp. 478-490, Feb. 2019.

[41]S. Marković, B. Jaćimović, S. Genić, M. Mihailović, U. Milovančević, and M. Otović, "Air side pressure drop in plate finned tube heat exchangers," Int. J. Refrig., vol. 99, pp. 24-29, Mar. 2019.

[42] T. Chen, J. Wang, and W. Peng, "Flow and heat transfer analyses of a plate-fin heat exchanger in an HTGR," Ann. Nucl. Energy, vol. 108, pp. 316-328, Oct. 2017.

[43] G. Zhou, Y. Ye, J. Wang, W. Zuo, Y. Fu, and X. Zhou, "Modeling air-to-air plate-fin heat exchanger without dehumidification," Appl. Therm. Eng., vol. 143, pp. 137-148, Oct. 2018.

[44]J. Wen, K. Li, C. Wang, X. Zhang, and S. Wang, "Optimization investigation on configuration parameters of sine wavy fin in platefin heat exchanger based on fluid structure interaction analysis," Int. J. Heat Mass Transf., vol. 131, pp. 385-402, Mar. 2019.

[45] Y. Guo, F. Wang, M. Jia, and S. Zhang, "Modeling of plate heat exchanger based on sensitivity analysis and model updating," Chem. Eng. Res. Des., vol. 138, pp. 418-432, Oct. 2018.

[46] W. M. Kays and A. L. London, "Compact heat exchangers," 1984.

[47] S. Sanaye and H. Hajabdollahi, "Thermal-economic multi-objective optimization of plate fin heat exchanger using genetic algorithm," Appl. Energy, 2010.

[48]H. Najafi, B. Najafi, and P. Hoseinpoori, "Energy and cost optimization of a plate and fin heat exchanger using genetic algorithm," Appl. Therm. Eng., 2011.

[49] N. Stathopoulos, M. El Mankibi, and M. Santamouris, "Numerical calibration and experimental validation of a PCM-Air heat exchanger model," Appl. Therm. Eng., vol. 114, pp. 1064-1072, Mar. 2017.

[50] S. A. Javed, A. Mahmoudi, A. M. Khan, S. Javed, and S. Liu, "A Critical Review: Shape Optimization of Welded Plate Heat Exchangers based on Grey Correlation Theory," Appl. Therm. Eng., vol. 144, pp. 593-599, Aug. 2018.

[51]F. G. Arias, El Proyecto de Investigación. Introducción a la metodología científica. 5ta. Fidias G. Arias Odón, 2012.

[52]I. S. Berezin and N. P. Zhidkov, "Computing Methods, Vol. I," Pergamon Press. Oxford).[3] Krylov, VI Approx. Calc. Integr. (Macmillan, New York-London).[4] Dedi6, LJ, Mati6, M. Pe6ari6, J.(2000)" Gen. ofOstrowski Inequal. via some Euler-type identities", Math. Inequal. App, vol. 3, no. 3, pp. 337-353, 1965.

[53]M. Mobtil, D. Bougeard, and S. Russeil, "Experimental study of inverse identification of unsteady heat transfer coefficient in a fin and tube heat exchanger assembly," Int. J. Heat Mass Transf., vol. 125, pp. 17-31, Oct. 2018.

[54]H. Liu, Y. Wang, D. Liu, S. Yuan, and J. Wang, "Assessment of a turbulence model for numerical predictions of sheet-cavitating flows in centrifugal pumps," J. Mech. Sci. Technol, vol. 27, 2013.

[55]T. Xiaoping, L. Huahe, and L. Xiangfei, "CFD simulation and experimental study on air- side performance for MCHX," Int. Refrig. Air Cond. Conf., p. 9, 2010.

[56] M. Khoshvaght-Aliabadi, F. Hormozi, and A. Zamzamian, "Role of channel shape on performance of plate-fin heat exchangers: Experimental assessment," Int. J. Therm. Sci., vol. 79, pp. 183-193,
May 2014.

[57]E. M. Smith, "Advances in Thermal Design of Heat Exchangers," John Wiley \& Sons, Inc. 2005.

[58] V. Bone, R. McNaughton, M. Kearney, and I. Jahn, "Methodology to develop off-design models of heat exchangers with non-ideal fluids," Appl. Therm. Eng., vol. 145, pp. 716-734, Dec. 2018.

[59]A. Persson, R. Lindstrand, S. Muggiasca, and L. Larsson, "CFD prediction of steady and unsteady upwind sail aerodynamics," Ocean Eng., vol. 141, pp. 543-554, Sep. 2017.

[60]G. Go and H. T. Ahn, "Hydrodynamic derivative determination based on CFD and motion simulation for a tow-fish," Appl. Ocean Res., vol. 82, pp. 191-209, Jan. 2019.

[61] S. Lal et al., "CFD modeling of convective scalar transport in a macroporous material for drying applications," Int. J. Therm. Sci., vol. 123, pp. 86-98, Jan. 2018.

[62]B. Zamora and A. S. Kaiser, "Enseñanza de temas avanzados de Mecánica de Fluidos usando Dinámica de Fluidos Computacional,' Form. Univ., vol. 2, no. 1, pp. 27-36, 2009.

[63]D. Ha and J. H. Jeong, "Performance characteristics of a combined air conditioner and refrigerator system interconnected via an intercooler," Int. J. Refrig., vol. 49, pp. 57-68, Jan. 2015.

[64] S. Alfarawi, R. AL-Dadah, and S. Mahmoud, "Transient investigation of mini-channel regenerative heat exchangers: Combined experimental and CFD approach," Appl. Therm. Eng., vol. 125, pp. 346-358, Oct. 2017.

[65]D. Taler and P. Ocłon,, "Thermal contact resistance in plate fin-andtube heat exchangers, determined by experimental data and CFD simulations," Int. J. Therm. Sci., 2014.

[66]A. Erek, B. Özerdem, L. Bilir, and Z. Ilken, "Effect of geometrical parameters on heat transfer and pressure drop characteristics of plate fin and tube heat exchangers," Appl. Therm. Eng., 2005.

[67]Z. Zhang and Y. Li, "CFD simulation on inlet configuration of platefin heat exchangers," Cryogenics (Guildf)., 2003.

[68]K. Boukhadia, H. Ameur, D. Sahel, and M. Bozit, "Effect of the perforation design on the fluid flow and heat transfer characteristics of a plate fin heat exchanger," Int. J. Therm. Sci., vol. 126, pp. 172180, Apr. 2018

[69] A. M. González, M. Vaz, and P. S. B. Zdanski, “A hybrid numericalexperimental analysis of heat transfer by forced convection in platefinned heat exchangers," Appl. Therm. Eng., vol. 148, pp. 363-370, Feb. 2019.

[70]R. Song, M. Cui, and J. Liu, "A correlation for heat transfer and flow friction characteristics of the offset strip fin heat exchanger," Int. J. Heat Mass Transf., vol. 115, pp. 695-705, Dec. 2017.

[71]H.-T. Chen, Y.-L. Hsieh, P.-C. Chen, Y.-F. Lin, and K.-C. Liu, "Numerical simulation of natural convection heat transfer for annular elliptical finned tube heat exchanger with experimental data," Int. J. Heat Mass Transf., vol. 127, pp. 541-554, Dec. 2018.

[72] L. S. Ismail, C. Ranganayakulu, and R. K. Shah, "Numerical study of flow patterns of compact plate-fin heat exchangers and generation of design data for offset and wavy fins," Int. J. Heat Mass Transf., vol. 52, no. $17-18$, pp. 3972-3983, 2009.

[73] C. Liu, W. Bu, and D. Xu, "Multi-objective shape optimization of a plate-fin heat exchanger using CFD and multi-objective genetic algorithm," Int. J. Heat Mass Transf., vol. 111, pp. 65-82, Aug. 2017.

[74]O. M. Ilori, A. J. Jaworski, and X. Mao, "Experimental and numerical investigations of thermal characteristics of heat exchangers in oscillatory flow," Appl. Therm. Eng., vol. 144, pp. 910-925, Nov. 2018.

[75]F. Roelofs and A. Shams, "CFD-Introduction," Therm. Hydraul. Asp. Liq. Met. Cool. Nucl. React., pp. 213-218, Jan. 2019. 